Original article

https://www.journal-imab-bg.org

\title{
RESEARCH OF THE POSSIBILITIES OF LASER ACUPUNCTURE IN MUSCULOSKELETAL DYSFUNCTIONS IN THE AREA OF THE SPINE
}

\author{
Stamenka Mitova ${ }^{1}$, Mariya Gramatikova ${ }^{1}$, Borislav Chongov $^{2}$, Margarita \\ Avramova ${ }^{1}$ \\ 1) Training sector of Kinesitherapy, Faculty of Public Health, Healthcare and \\ Sports, Department of Kinesitherapy, South-West University Neofit Rilski, \\ Blagoevgrad, Bulgaria \\ 2) Medical center Orthomed, University Hospital for Active Treatment of \\ Orthopaedics "Prof. BoichoBoichev", Sofia, Bulgaria.
}

\section{SUMMARY}

The study aims to investigate (evaluate) the effect of laser acupuncture on musculoskeletal spine dysfunctions.

Material and Methods: 35 people (participants) with musculoskeletal spine dysfunctions were recruited. Anamnesis, somatoscopy, Schober test, Ott test, Lasegue test and VAS scale were used for assessment before and after treatment. The participants received MLS-laser therapy (laser acupuncture) daily for 10 days with a duration of $10 \mathrm{~min}$ utes per procedure. The results (Data) were analyzed using Prism 3.02

Results: 35 participants, including 15 women and 20 men, were examined. The mean age of the observed contingent $\left(\bar{X}_{ \pm} \mathrm{SD}\right)$ in females is $48 \pm 6.3$ years and in males $53 \pm 4.3$ years. Median values of the Ott test before and after the MLS treatment were as follows: $2.46 \pm 0.44 \mathrm{~cm}$, and $4.27 \pm 0.56 \mathrm{~cm}$. Shober's test shows $1.60 \pm 0.43 \mathrm{~cm}$ before and $2.83 \pm 0.63 \mathrm{~cm}$ after treatment. The test of Lasegue shows $67.43 \pm 4.27^{\circ}$ before and $82.57 \pm 4.09^{\circ}$ after. The average of pain measured before and after treatment was $8.91 \pm 1.01 \mathrm{~mm}$ and $1.71 \pm 0.79 \mathrm{~mm}$, respectively. There were statistically significant differences before and after treatment $(\mathrm{p}<0.05)$.

Conclusions: Data demonstrate the efficacy and positive effect of applied MLS therapy in patients with musculoskeletal spine dysfunctions. Treatment significantly reduces pain and muscle spasm after application and improves the quality of life of patients with this dysfunction. Laser therapy not only helps the reduction of painful symptoms in musculoskeletal pathologies but is also a valuable tool for rehabilitation.

Keywords: laser, rehabilitation, acupuncture, spine, dysfunctions, prevention, treatment.

\section{INTRODUCTION}

Pain in the thoracic and lumbar region, which is defined as a non-specific, epidemiological condition, may be the result of a variety of injuries. It is not a disease but a symptom in which, in many cases, etiology is unknown. Pain in the thoracic and lumbar region is a common problem in kinesitherapeutic practice. The percentage of people affected reaches $80 \%$ [1].

Musculoskeletal disorders are the most common cause of severe and persistent pain. In Europe, 20-30\% of the population is affected by this problem [2].

Over the past century, global health priorities were largely focused on communicable diseases. With the world's population growth, increased average age and decreased death rates, people are now living longer and becoming increasingly susceptible to non-communicable diseases, including musculoskeletal (MSK) disorders. The recent Global Burden of Disease (GBD) Study estimated the burden disability in 187 countries and 21 regions of the world for the years 1990, 2010 and 2013 of all MSK disorders - osteoarthritis (OA), rheumatoid arthritis (RA), gout, low back pain (LBP), neck pain (NP) and all other musculoskeletal disorders. Throughout the world, the prevalence and burden from MSK conditions were exceptionally high. All MSK disorders combined caused 21.3\% of the total years lived with disability (YLDs) globally second to mental and behavioural problems $(23.2 \%)$ [3].

Three of the most common causes of musculoskeletal spine dysfunctions associated with (cervical, thoracic or lumbar spine) are chronic cervical pain without additional complications, back pain and lumbar pain, with a frequency of $18 \% 17.7 \%$ and $36 \%$ [4, 5]. These three conditions adversely affect the quality of life of the patient, creating a significant economic and social burden [6].

Epidemiological data show a strong correlation between cervical pain and lumbar pain, which can be considered one of the causes [7]. Although these conditions occur in different parts of the body, we can summarize these as chronic musculoskeletal spine pain in accordance with pathogenesis. Treatment includes medicines, physiotherapy, patient training and other interventions, but the effect of treatment is unsatisfactory $[8,9,10]$.

There are a number of studies on the effect of using different physiotherapeutic methods and devices that 
would have a positive effect on limiting factors (pain, stiffness, reduced ability to work, etc.) and would improve the quality of life of such patients. In recent years complaints of back pain have increased. Studies show that it may be related to modern lifestyle.

Laser MLS therapy is an innovative therapy for the treatment of pain, inflammation and efflux, as well as for the regeneration of soft tissues. This technique is based on the work of diode lasers and has strong anti-inflammatory, analgesic and anti-edematous effect. MLS Laser therapy has better homogeneity and energy distribution.Through the syncing action specific to laser MLS therapy, a complex of a refined and light pulse can be obtained that has the ability to transfer energy to the target anatomical structures with very high efficiency.Theemitted energy is directed through an optical group and distributed evenly over a large area set for the purpose of the procedure.This energy facilitates the activity of photoreceptors in the treated area, the patient quickly overcomes pain in the long termand can get back to normal activity in daily life - work, sports, social activity.

\section{MATERIAL AND METHODS}

The study includes 35 patients (15 females and 20 males) mean age ( \pm SD) for women $48 \pm 6.3$ years, and 53 $\pm 4.3 \mathrm{~g}$ for males randomly chosen and according to the indications for the application of the experimental methodology. Functional tests and physiotherapy procedures were conducted after informed written consent. The study methodology includes conducting functional tests - an anamnesis (including physical exercise data, motor behavior, etc.), somatoscopy (view), Shober Test, Ott Test, Lasegue test and Visual Analog Scale (VAS).

The examination of the pain was done through experimentally induced palpation pain (applying the same pressure, by the same person) in trigger point (TP) and evaluated with VAS. Values of pain were measured before MLS-laser (laser acupuncture) therapy and after treatment. VAS is a scale to evaluate pain perception with a length of $100 \mathrm{~mm}$. The left end of the scale reflects a level of "no pain", and the right - "very strong pain". After palpation in PT, the patient indicates the point on the scale that he thinks reflects the strength of his pain perception at the moment. The intensity of pain is recorded as the length in millimeters, measured from the left end of the scale to the point indicated by the patient. MLS laser therapy (laser acupuncture) is conducted daily for 10 days, with an application for a thoracic dose of $\mathrm{C} 7$ to $\mathrm{T} 9$ and a lumbar fraction of L2 to S2 for no more than 10 minutes per procedure. The first 3-4 procedures at a frequency of $500-700 \mathrm{~Hz}$ (at a dose of $1.3 \mathrm{~J} / \mathrm{cm}^{2}$ ); in the last $7-10$ procedures, the frequency is increased to $1500 \mathrm{~Hz}$ (dose $1.3 \mathrm{~J} / \mathrm{cm}^{2}$ ). The results are statistically processed with variance analysis using Prism 3.02. Wilcoxon test was applied to prove statistically significant differences of obtained data before and after treatment [11, 12].

\section{RESULTS}

35 people, including 15 women and 20 men, were recruited. The mean age of the observed contingent ( \pm SD) in females is $48 \pm 6.3 \mathrm{~g}$, and in men $53 \pm 4.3$ years, mean values of height and weight are as follows for women 170 $\pm 3.2 \mathrm{~cm}$ and $74 \pm 8.0 \mathrm{~kg}$., in men $170 \pm 3.8 \mathrm{~cm}$ and 100 $\pm 7.5 \mathrm{~kg}$. The mean values $( \pm \mathrm{SD})$ of the Ott test measured before treatment in patients with musculoskeletal spine dysfunctions were $2.46 \pm 0.44 \mathrm{~cm}$. At the end of the procedures, the range of movement in the thoracic spine increased to $4.27 \pm 0.56 \mathrm{~cm}$. Obtained data for the range of movement are shown in Table 1 . The differences in data in both measuring periods were statistically significant ( $\mathrm{p}$ $<0.05)$.

Table 1. Ott test data before and after the MLS-therapy in patients with musculoskeletal spine dysfunction.

\begin{tabular}{|c|c|c|c|c|c|c|}
\hline Ott test $\boldsymbol{N}-\mathbf{3 5}$ & $\bar{X}$ & St. Deviation & X max. & X min. & Std. Error & V\% \\
\hline Before MLS-therapy & 2.46 & 0.44 & 3.0 & 2.0 & 0.08 & $18.05 \%$ \\
\hline After MLS-therapy & 4.27 & 0.56 & 5.0 & 3.5 & 0.56 & $13.12 \%$ \\
\hline
\end{tabular}

The mean values $( \pm$ SD) of the Shober test presented in Table 2 measured before and after the MLS therapy in patients with musculoskeletal spine dysfunctions were respectively $1.60 \pm 0.43 \mathrm{~cm}$ and $2.83 \pm 0.63 \mathrm{~cm}$. So the range of movement in lumbar spine increase with statistically significant difference $(\mathrm{p}<0.05)$.

Table 2. Shober test data before and after the MLS-therapy in patients with musculoskeletal dysfunction in the spine

\begin{tabular}{|c|c|c|c|c|c|c|}
\hline Shobertets $\boldsymbol{N}-35$ & $\bar{X}$ & St. Deviation & X max. & X min. & Std. Error & V \% \\
\hline Before MLS-therapy & 1.60 & 0.43 & 2.0 & 1.0 & 0.07 & $27.12 \%$ \\
\hline After MLS-therapy & 2.83 & 0.63 & 4.0 & 2.0 & 0.11 & $22.25 \%$ \\
\hline
\end{tabular}

The mean values $\left( \pm\right.$ SD) of the Lasegue test presented in Table 3 measured before therapy were $67.43 \pm 4.27^{\circ}$. At the end of the procedures, the range of motion of the hip increased to $82.57 \pm 4.09^{\circ}$. The differences in the range of motion values in the two measurement periods were statistically significant $(\mathrm{p}<0.05)$. 
Table 3. Lasegue test data before and after the MLS-therapy in patients with musculoskeletal dysfunction in the spine

\begin{tabular}{|c|c|c|c|c|c|c|}
\hline Lasseg test $N-35$ & $\bar{X}$ & St. Deviation & X max. & X min. & Std. Error & V \% \\
\hline Before MLS-therapy & 67.43 & 4.27 & 75.00 & 60.00 & 0.72 & $6.33 \%$ \\
\hline After MLS-therapy & 82.57 & 4.09 & 90.00 & 70.00 & 0.69 & $4.95 \%$ \\
\hline
\end{tabular}

The mean value $( \pm$ SD) of the pain measured before MLS therapy in patients with the musculoskeletal spine was $8.91 \pm 1.01 \mathrm{~mm}$. After treatment, the mean value of pain was reduced to $1.71 \pm 0.79 \mathrm{~mm}$. Data differences in the two measurement periods were statistically significant $(\mathrm{p}<0.05)$. The Visual-Analog scale data of pain is presented in Table 4.

Table 4. Visual analogue scale (VAS) data before and after the MLS-therapy in patients with musculoskeletal dysfunction in the spine

\begin{tabular}{|c|c|c|c|c|c|c|}
\hline VAS $\boldsymbol{N}-\mathbf{3 5}$ & $\bar{X}$ & St. Deviation & X max. & X min. & Std. Error & V \% \\
\hline Before $\boldsymbol{M L S}$-therapy & 8.91 & 1.01 & 10.00 & 6.000 & 0.17 & $11.34 \%$ \\
\hline After $\boldsymbol{M L S}$-therapy & 1.71 & 0.79 & 4.00 & 1.00 & 0.13 & $46.00 \%$ \\
\hline
\end{tabular}

\section{DISCUSSION}

Our results show a high reduction of the pain and increased the range of motion in the cervical and lumbar area of the spine. MLS-therapy (laser acupuncture) in patients with spinal musculoskeletal dysfunctions has proven effectiveness and positive effect reducing pain symptoms and muscle spasm in the course of the treatment. The effectiveness of acupuncture as a method of treating various diseases has also been reported in many high-quality clinical trials [13, 14, 15].

More and more clinical studies have reported that acupuncture is effective for musculoskeletal dysfunctions, including chronic neck pain, thoracic and lumbar pain [16].

Laser therapy is a non-invasive, painless method of treatment and helps overcome the painful symptoms typical of musculoskeletal pathologies.

Light has healing properties and has been considered a source of life for centuries. No living organism can survive without light. It regulates biological rhythms of most living creatures that can absorb lightdue to specific photoreceptors. It has been scientifically proven that certain types of radiation can efficiently transfer energy to cells and tissues as a result of which the metabolism normalizes in the problem areas and the damaged tissues recover.
The synergistic effect of MLS therapy is achieved through the physical characteristics of the MLS pulse. This is a special complex type of radiation that transmits the energy of the electromagnetic field into tissues in the most effective way. Thus, this light pulse has maximum biological and therapeutic properties and is generated by a synchronized combination of impulse and continuous waves of varying lengths. Laser therapy plays a very important role in physiotherapy and is used daily in clinics.

\section{CONCLUSION}

Data presented demonstrate the efficacy of MLS therapy in patients with musculoskeletal spine dysfunctions. The strong reduction in pain symptoms and muscle spasm in the course of the treatment improves the quality of life of patients. Laser therapy not only helps overcome the painful symptoms typical of musculoskeletal pathologies but is also a valuable tool for rehabilitation.

\section{Acknowledgments:}

This article is supported under Project No. RP-A1/ 19, Project topic: Research The Possibilities Of Laser Acupuncture For Musculoskeletal Dysfunctions In The Spinal Column Region.

\section{REFERENCES:}

1. Nenova G, Filkova S, Nedev N. Physioterapeutic view on the management of low back pain. Varna Medical Forum. 2016; 5 (3):162-165. [Internet]

2. Hagen KB, DagfinrudH, Moe RH, Østerås N, Kjeken I, Grotle M, et al. Exercise therapy for bone and muscle health: an overview of systematic reviews. BMC Med. 2012 Dec 19; 10:167. [PubMed] [Crossref]

3. Woolf AD. Global burden of osteoarthritis and musculoskeletal diseases. Proceedings of the Musculoskeletal Health in the 21st Century Workshop. BMC Musculoskeletal Disorders. 20151 December 2015; 16:1: S3 [PMC]

4. Gerhardt A, Hartmann M, Blumenstiel K, Tesarz J, Eich W. The prevalence rate and the role of the spatial extent of pain in nonspecific chronic back pain-apopulation-based study in the south-west of Germany. Pain Med. 2014; 15:1200-10. [PubMed]

5. Hoy D, Bain C, Williams G, March L, Brooks P, Blyth F, et al. A systematic review of the global prevalence of low back pain. Arthritis Rheum. 2012; 64:2028-37. [PubMed]

6. Buchbinder R, Blyth FM, March LM, Brooks P, Woolf AD, Hoy DG. Placing the global burden of low back 
pain in context. Best Pract Res Clin Rheumatol. 2013; 27:575-89. [PubMed]

7. Lu S-C, Zheng Z, Xue CC. Does acupuncture improve quality of life for patients with pain associated with the spine? A systematic review. Evid Based Complement Alternat Med. 2011; 2011:1741-427X. [PubMed]

8. Enthoven WT, Roelofs PD, Deyo RA, van Tulder MW, Koes BW. Nonsteroidal anti-inflammatory drugs for chronic low back pain. Cochrane Database Syst Rev. 2016 Feb 10;2: (2)CD012087. [PubMed]

9. Bruflat AK, Balter JE, McGuire D, Fethke NB, Maluf KS. Stress management as an adjunct to physical therapy for chronic neck pain. Phys Ther. 2012 Oct; 92(10):1348-59. [PubMed]

10. Kuijpers T, van Middelkoop M, Rubinstein S, Ostelo R, Verhagen A, Koes BW, et al. A systematic review on the effectiveness of pharmacological interventions for chronic non-specific low-back pain. Eur Spine J. 2011 Jan; 20(1):40-50 [PubMed]

11. Karashtranova E. [Interactive training on probabilities and statisticstextbook of a monographic nature.] [in Bulgarian] University Publishing House SWU „Neofit Rilski”, Blagoevgrad. 2010. pp.75-77.

12. Karashtranova EL, Stoimenova EA. [Analysis of the efficacy of experimental teaching on combinatorics, probability and statistics at high school.] [in Bulgarian] Mathematics and Education in Mathematics, Varna. 2007. pp.376-382. [Internet]

13. Zhao L, Chen J, Li Y, Sun X, Chang X, Zheng H, et al. The long-term effect of acupuncture for migraine prophylaxis: a randomized clinical trial. JAMA Intern Med. 2017; 177:508-15. [PubMed]

14. Hershman DL, Unger JM, Greenlee H, Capodice JL, Lew DL,
Darke AK, et al. Effect of acupuncture vs sham acupuncture or waitlist control on joint painrelated to aromatase inhibitors among women with earlystage breast cancer: a randomized clinical trial. JAMA. 2018 Jul 10; 320. [PubMed]

15. Lesi G, Razzini G, Musti MA, Stivanello E, Petrucci C, Benedetti B, et al. Acupuncture as an integrative approach for the treatment of hot flashes in women with breast cancer: a prospective multicenter randomized controlled trial (AcCliMaT). J Clin Oncol. 2016 May 20; 34(15):1795802. [PubMed]

16. Sherman KJ, Cherkin DC, Ichikawa L, Avins AL, Barlow WE, Khalsa PS, et al. Characteristicsof patients with chronic back pain who benefit from acupuncture. BMC Musculoskelet Disord. 2009 Sep 21; 10:114. [PubMed] [Crossref].

Please cite this article as: Mitova S, Gramatikova M, Chongov B, Avramova M. Research of the Possibilities of Laser Acupuncture in Musculoskeletal Dysfunctions in the Area of the Spine. J of IMAB. 2020 Jul-Sep;26(3):3298-3301.

DOI: https://doi.org/10.5272/jimab.2020263.3298

Received: 24/09/2019; Published online: 26/08/2020

\section{Address for correspondence:}

Assoc. Prof. Stamenka Mitova, PhD

Faculty of Public Health, Healthcare and Sports, Department of Kinesitherapy, South-West University NeofitRilski

66, Ivan MihaylovS tr., 2700 Blagoevgrad, Bulgaria.

E-mail: stami80@abv.bg 